\title{
Social Networks and Personal Security
}

\author{
Patryk Błasik ${ }^{1}$ \\ ${ }^{1}$ WSB University \\ ul. Cieplaka 1C, 41-300 Dąbrowa Górnicza - Poland
}

\begin{abstract}
The emergence of the Internet caused a significant simplification of interpersonal communication all over the world. True, the communication became fast, cheap and convenient and for people, who by nature are social beings, it enabled easy bonding, maintaining relationships and strengthened the feeling of belonging to one group or another. Along with development of the Internet social networking portals emerged becoming a popular means of communication and entertainment specifically dedicated to young people. The paper outlines the most important advantages and disadvantages of social networks especially with respect to security.
\end{abstract}

Index Terms - social network, personal security, the Internet, threats.

\section{INTRODUCTION}

What is a social network? In Poland there is no legal definition of the concept, but the term is usually defined as a website, a tool used to build social networks and social relations of specific groups, mostly based on common interests and shared private or professional life. In the literature on the subject, the concept of a social network is used interchangeably with a social networking site. The beginnings of social networks date back to the 1990s. One of the first social network sites was a portal called Classmates.com, created in 1995 in the United States, a website used to communicate with former school friends. The portal was created by Rande Conrads. But the real breakthrough occurred in 2004, with introduction of Facebook on electronic social networking market (the premiere of the Polish language version took place in 2008). Facebook, the most famous social networking site so far, was created by a Harvard University student, Mark Zuckerberg (Warzecha, 2017). Initially, the portal was used for communication between students. Currently, thanks to this service, users can publish the so-called statuses, photos, short films, react and comment on posts, make and participate in various events, create their own fanpages, run advertising campaigns, play games and much more.

Other popular social networking sites currently in operation include:

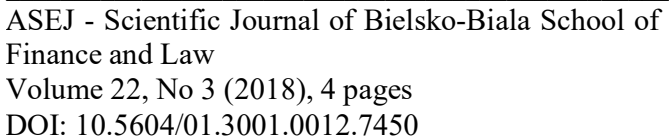

Received 03 September 2018; Accepted 17 September 2018
- YouTube.com (a portal enabling free posting and playback of videos),

- Instagram (photo social networking site based on photo hosting),

- Twitter (a portal that allows for micro-blogging by posting tweets),

- Photoblog (type of an online blog, diary with an option of posting comments),

- Linkedin.com (a social networking site for establishing business contacts),

- GoldenLine (social network for people wanting to develop their professional career).

In addition to the Internet portals indicated above, there are also mobile applications for social networks which are very popular among young people. These include: Snapchat (application used for posting short videos as part of relations that disappear after a certain time), WhatsApp (messenger for sending messages, voice and video calls) or Tinder application (a dating application where you set up your own profile with a photo).

When it comes to Polish websites which can be included under the spectrum of social networking, naszaklasa.pl (today nk.pl) should be brought to the readers' attention, the founders of this portal were Polish students of computer sciences at the University of Wrocław - Maciej Popowicz, Paweł Olchawa, Michał Bartoszkiewicz and Łukasz Adziński. The idea behind naszaklasa.pl was to find, renew and maintain contacts with mates from school. Another example of a Polish social networking site is fotka.pl (now fotka.com) where users can post their photos, rate photos of others, comment and freely communicate.

\section{FACTS AND FIGURES RELATED TO SOCIAL NETWORKING SITES}

According to statistics quoted by the Central Statistical Office, in $201781.9 \%$ of Polish households had access to the Internet. This percentage was higher by $1.5 \mathrm{pp}$. than in the previous year, and by $7.1 \mathrm{pp}$. when compared to 2014 (Stat.gov.pl, 2018). In December 2017, the most frequently

Regular research paper: Published 15 October 2018

Corresponding author's e-mail: p.blasik@interia.pl

Copyright $(C) 2018$ This is an open access article distributed under the Creative Commons Attribution CC-BY-NC 4.0 License. 
visited sites by users of the Polish Internet also in terms of time spent online, were: Google Group sites, Facebook and YouTube. In the light of a report conducted by IBA Poland for 2017, Facebook remains the leader of social networking sites in Poland with the range of $82 \%$. Fotka.com, in turn, ranks first in terms of the average number of views per user (Raport Strategiczny „Internet” 2017/2018, 2018). As can be seen from the statistics provided above, social networking sites play a huge role in the lives of Internet users as they fulfill several functions at the same time, e.g. they provide communication, information, entertainment and social life.

According to a EU-NED-ADP3 research, social networking sites are the most common form of online activity for European youth aged 14-17, 90\% of the surveyed youth had at least one profile on a social networking site. This form of entertainment is more popular among girls than among boys, and people who spend on social networks at least 2 hours per day, more often overcome loneliness via the Internet than other users. At the same time, the studies described above have shown that people using social networks are more likely to intensively use the Internet and are under greater threat of abuse or addiction (Warzecha, 2017).

\section{THE IMPACT OF SOCIAL NETWORKS ON PERSONAL SECURITY}

Social networking sites opened a new era of communication with new possibilities such as adding posts, photos or film stories etc. These activities undoubtedly allow to overcome loneliness, build a certain social status and maintain interpersonal relations. But besides all the advantages of social networking sites, one must not overlook serious drawbacks that may affect personal security of users, especially the young ones. The term 'generation Z' refers to people born after 2000, these young people are certainly unaware of the threats lurking on them from their favourite sites. Let's take a closer look at portals such as Facebook, Instagram or fotka.com on which young people post entries, photos or videos and by doing so they virtually expose their entire life.

In my professional live I have conducted hundreds of preventive meetings with young people regarding online safety, I can confidently say that their approach to social networking sites matches my need to have obligatory breakfast in the morning. They cannot survive a day without the access to the Internet just as I could not function normally without breakfast. The question that I always ask young people is: Are you aware that once uploaded, the film or photo will remain on the Internet forever? $99.9 \%$ of them give me a positive answer. Yes, they are aware. So then I ask: Why did you upload them? Unfortunately, to this question I do not receive a substantive answer. So, what is the risk of uploading a personal photo or video on the Internet? When people post something on the Internet, on a social network, they can never be certain that someone, a friend or a stranger, will not save this photo or movie on their device or a carrier. Young people will probably reply 'so what?' In response I will quote statistics of CERT Polska (CERT Polska, 2018) which is the first computer emergency response team established in Poland. According to a CERT report on internet incidents, in 2016 alone, 1020 of these incidents concerned identity theft, including creating fictitious Facebook accounts that used images of existing people. Interestingly enough, the use of someone's image in a way that is not defamatory without the consent of the person in the photograph, does not violate the provisions of the Polish criminal law, and the incident can be pursued only on the civil law path.

The pictures and messages posted by young people on social networking sites are frequently of intimate, explicit and very private nature, which in the literature of the subject is called sexting. According to a research carried out in 2014 by the 'Dzieci Niczyje' foundation, sexting is one of the threats that has started to be discussed in Poland only recenty. The first study conducted among young people aged 15-19 showed that the scale of the problem is relatively large. $45 \%$ of respondents were aware that their friends and colleagues post such contents online. Only a small proportion declared that they did not know anyone who did so. Slightly over 1/3 (34\%) admitted that they themselves received sexting materials, and every ninth (11\%) confessed to actually sending such contents. Those who were recipients of such messages claimed that most often they were an attempt to "pick them up" (and not flirt with an existing partner, boyfriend or girlfriend). Relatively often such messages were sent to the respondents not by the people they knew but by strangers. In turn, those who declared sending sexts claimed that they were intended to their boyfriends/girlfriends (Fdn.pl, 2018). Speaking of sexting, it should not be overlooked that persons displaying, sharing, disseminating pornographic content to persons under 15 years of age (Article $200 \S 3$ of the Penal Code) are criminally liable. This liability applies to both adults and minors who, acting in this way even in the form of a joke, may expose themselves to liability for a criminal act or a manifestation of demoralization.

In 2015 a YouTuber operating under the name "Z dobrym słowem - Rafał Jarząbek" came up with a very interesting idea. In a short spot 'Be careful what you post. Social media stalker with a good word', he showed how much information can be extracted from public accounts on Facebook. Following profiles of several young women he was able to determine their current whereabouts, what they did a few hours earlier, since when they had been in Warsaw, what their boyfriend or dog was called etc. The women whom he approached directly in the street, did not believe the questions he asked, initially they responded with a smile, but over time they were overwhelmed with horror about how much a stranger knows about them. The entire experiment also had a preventive finale. The two women to whom the YouTuber spoke, blocked access to their social accounts to strangers after this meeting. I believe that footage I have just quoted should be a great warning for users of social networks.

At present, there is a feeling of mixed emotions in Poland caused by the concept of the newly introduced EU data protection regulation GDPR, which is to protect our personal data against misuse. However, we as users of social networks and holders of different profiles certainly do not protect our 
own data in an appropriate way. The information about the place of work or study posted on a social network will help people with ill intentions to determine our address or address of the school, company etc. The question to be answered here is 'why should a criminal want to know my address?' The answer is easy, in the world there are many disturbed, psychopathic people, stalkers, bullies etc. We make it easy for them to follow us and find out information we would not like them to know. There are also jealous people, someone may like our new phone or car, which we proudly posted a few minutes earlier.

The next disadvantage of using social networking sites is the lack of anonymity and a greater risk of being exposed to various types of cyberbullying, which constitute acts prohibited by law. Another serious and perceptible problem is hate. Hate can be manifested not only by words, but also graphics (memes, gifs) or videos - in the last two cases, unfortunately, they are so much easier to remember. It is worth noting that the contents added by the haters have no substantive value, they are only directed against a given person or a group of people. Polish PWN Dictionary defines the word 'hate' (spelt 'hejt' in Poland) as an offensive or aggressive comment posted on the Internet (Sjp.pwn.pl, 2018). From legal point of view, hate can be a onetime incident and it will be considered in terms of a crime of defamation (Article 212 of the Penal Code) or indignity (Article 216 of the Penal Code), multiple cases of hate where such behavior will deplete the signs of stalking, or persistent harassment will be considered pursuant to Article 190a of the Penal Code. Hate is also a dangerous phenomenon from psychological point of view. Many victims of hate cannot cope with the hatred directed towards them on the Internet, as a consequence they become depressive and even suicidal. From my own professional experience in which I frequently participate in juvenile proceedings, I can say with full responsibility for my words, that hate is a common and widespread phenomenon among young people aged 12-16. Unfortunately, the Polish legal system does not provide appropriate tools that can protect an aggrieved teenager (victim of cyberbullying) from such attacks.

Another common phenomenon is using social networking sites for dissemination of the so-called fake news. As an example of a real threat to the safety of children on the Internet, I will quote information that appeared in the media in the first quarter of 2017, the news related to the 'Blue Whale Game'. The media reported that a dangerous game caused 130 suicides of children across Russia. The unverified information has been repeatedly disseminated by various journalists. It was the media who created the game using the 'Chinese whispers' method. Authors of the information related 130 suicides from 2015 and 2016 with the described game. The rules of the game assumed that it must be played in pairs or groups. In order to join, one had to find a 'guardian' through social media. The task of the supervisor was to assign tasks that the second person called a 'whale', would perform. Fifty tasks, such as self-injury or waking up in the middle of the night and watching movies that cause negative emotions, should be completed in fifty consecutive days. The last task was to commit suicide (Dyzurnet.pl, 2018). In Poland, several dozen of cases of self- injury were recorded; namely young people were cutting the whale symbol in the skin of their arms. Currently, a similar game called the 'MOMO Challenge' appeared on the Internet. The game also relies on performing tasks ordered by a guardian, who has a motif of a Japanese MOMO doll in the profile photo (Zachodni et al., 2018).

The very same tool of fake news can also be used for political reasons. A good example can be the presidential elections in France that took place in 2017. Cyberdefence24.pl reports: French voters were literally flooded with fake Twitter news before the presidential election whose first round was conducted on April 23, 2017. Researchers at Oxford found that much of the published fake news came from sources that could have had connections with Russia. Researchers at the University of Oxford have proved that as much as a quarter of the information on presidential elections in France that were published on Twitter was false. The analyzed fake news has been identified as deliberately false, promoting extreme views, with logical errors and opinions presented as facts (CyberDefence24.pl, 2018).

The Internet fashion for challenges described above is a very disturbing phenomenon that has an impact on the personal safety of users of social networks. Some of the challenges are fun and safe, for example those related to pretending mannequins by larger groups in a 'Mannequin Challenge'. Challenges may arise in opposition to certain phenomena, e.g. racist behavior, as in the case of 'We Are All Monkeys'. Another example of this type of challenge is a social action called the 'Ice Bucket Challenge', whose aim was to raise public awareness of amyotrophic lateral sclerosis. Unfortunately, there are also dangerous forms of challenges, such as the ' 72 hours challenge', in which the participants are expected to escape from home and hide for 72 hours, or the 'Tide Pod Challenge', whose aim was to put a Tide Pod washing capsule into the mouth (Tide Pod Company decisively separated itself from this type of behavior, informing about the dangers of its implementation). Recently, the 'Kiki challenge' has also become popular on the Internet, in this challenge the dared person must get out of a moving vehicle and perform a dance to the song of an artist known under the pseudonym Kiki, this challenge poses a real threat to road safety. There are many compilations of accidents on youtube.com that occurred during the execution of the Kiki dance (e.g. people get hit by approaching vehicles).

\section{CONCLUSIONS}

Social networking sites have become an invaluable source of information and an important tool for communication and entertainment. It can be said that the young people living in contemporary world do not imagine life without social networks, such as Facebook, Instagram, Snapchat and others. This is evidenced by the research conducted by IAB Poland in 2017 quoted in the present paper. However, it should be noted that in addition to information, communication and entertainment, social networks carry real threats that may result in exposure to the image of users, risk to their own personal 
safety and their loved ones. We must start using social media wisely, we must always follow the principle of limited trust. Should we discover any inappropriate or suspicious behaviour on the Internet we should immediately report them to relevant institutions in Poland dealing with combating and preventing cybercrime, such as e.g. the Academic Computer Network (NASK).

\section{REFERENCES}

Warzecha, K. (2017). Portale społecznościowe formą rozrywki i komunikacji współczesnej młodzieży - analiza statystyczna. Studia Ekonomiczne, 318, p.86.

Stat.gov.pl. (2018). Główny Urząd Statystyczny. [online] Available at: http://stat.gov.pl/ [Accessed 17 Oct. 2018].

Raport Strategiczny „Internet” 2017/2018. (2018). [online] IAB Polska. Available at: https://iab.org.pl/badania-i-publikacje/raport-strategicznyinternet-20172018/ [Accessed 17 Oct. 2018].

CERT Polska. (2018). Strona główna - CERT Polska. [online] Available at: https://www.cert.pl/ [Accessed 17 Oct. 2018].

Fdn.pl. (2018). Fundacja Dzieci Niczyje. [online] Available at: http://fdn.pl/ [Accessed 17 Oct. 2018].

Sjp.pwn.pl. (2018). Stownik języka polskiego PWN. [online] Available at: http://sjp.pwn.pl/ [Accessed 17 Oct. 2018].

Dyzurnet.pl. (2018). [online] Available at: https://dyzurnet.pl/ [Accessed 17 Oct. 2018].

Dziennik Zachodni, (2018). Lalka Momo Challenge: Wstrząsające fakty o grze straszna laleczka MOMO To grozi śmiercia - policja ostrzega rodziców. [online] Dziennikzachodni.pl. Available at: https://dziennikzachodni.pl/lalkamomo-challenge-wstrzasajace-fakty-o-grze-straszna-laleczka-momo-to-grozismiercia-policja-ostrzega-rodzicow/ar/13550474 [Accessed 17 Oct. 2018].

CyberDefence24.pl. (2018). Francuskie wybory petne fake news. [online] Available at: https://www.cyberdefence24.pl/francuskie-wybory-pelne-fakenews [Accessed 17 Oct. 2018]. 